\title{
Repellent Effects on Distribution of Steers on Native Range
}

\author{
D.M. ENGLE AND J.G. SCHIMMEL
}

\begin{abstract}
Range livestock production and uniform use of ranges are often limited by poor distribution of livestock over the range. A repellent was applied to preferred grazing areas (subirrigated range sites) of a mixed prairie range in northcentral South Dakota. Cow chips were used as a measure of occupation of yearling steers on sites where the repellent was applied. Comparison sites did not receive a repellent application. There was no significant difference in chip numbers between the 2 treatments. However, there was a nonsigniffcant short-term decline in cow chips deposited on repellentsprayed subirrigated sites. Steers appeared to be marginally displaced from the sprayed subirrigated sites to adjacent unsprayed silty range sites.
\end{abstract}

Proper use of a range, although dependent upon many factors, is often complicated by poor distribution of livestock. Animals naturally congregate at preferred locations. Cattle prefer accessible areas such as valley bottoms, low saddles between drainages, level benches, mesas and areas adjacent to water sources. Drainageways often receive additional run-in moisture from surrounding slopes. The additional moisture results in a continuous supply of palatable, regrowth forage during the growing season which attracts cattle and leads to overutilization. The same areas are sometimes critical habitat areas for wildlife or critical management areas for other uses. Areas which are steep, rough, or are distant from water are least preferred by cattle and are usually underused or unused (Mueggler 1965; Cook 1966). Overgrazing of a range is commonly a result of nonuniform distribution in which the preferred use areas are overused and nonpreferred areas are underused. By obtaining more uniform use of an entire range, range condition may be improved on the preferred areas. Uniformity of use allows increased stocking rates without attendant overuse of any area on the range.

Salting, an inexpensive method to improve distribution of use in underused areas, may not be effective in reducing utilization near water (Martin and Ward 1973). Water developments can be used effectively to control utilization, but usually require construction of additional watering facilities, controlling access to water sources, or hauling water. Drift fences or cross fences effectively control access to preferred areas. Fences and water developments are usually permanent and costly range improvements. Roads and trails have been found to be effective in improving access and use of inaccessible areas (Workman and Hooper 1968), but do not appear to reduce use on preferred areas (Roath and Krueger 1982). Generally, management practices to improve uniformity of grazing use have been designed to prevent access to preferred areas (e.g. fences) or to attract animals to nonpreferred areas (e.g. water, salt or trails). To our knowledge, no studies have been conducted on

\footnotetext{
Authors were assistant professor and instructor, Department of Animal and Range Sciences, South Dakota State University, Brookings 57007. Currently Engle is associate professor, Agronomy Department, Oklahoma State University, Stillwater 74078, and Schimmel is Extension livestock specialist, South Dakota State University, West River Agricultural Research and Extension Center, Rapid Center, S. Dak. This report is contribution No. 1905. Journal Series, South Dakota Agr. Exp. Sta.

The authors express appreciation to the Nature Conservancy for providing the study area and to TNC staff who provided invaluable assistance in conducting this study. DEER-AWAY, Minneapolis, Minn., is acknowled ged for providing a portion of the repellent used in this study.

Manuscript received April 11, 1983
}

practices or methods used to repel livestock from preferred use areas. This study was designed to test the effectiveness of a repellent to deter steer occupation of preferred areas.

\section{Methods and Materials}

The study was conducted in 1982 on the Samuel H. Ordway Memorial Prairie in northcentral South Dakota, about $10 \mathrm{~km}$ west of Leola. The area is mesic mixed prairie in the glaciated pothole region of the Northern Great Plains. Topography of the area is gently undulating to undulating with slopes of less than $6 \%$. Drainage patterns on these glacial till plains are not well developed so that the landscape is characterized by dry uplands interrupted by mesic, often ponded depressions (potholes). These depressions are a minor portion of the land area. The average annual precipitation at Leola is approximately $50 \mathrm{~cm}$ with a single peak of $10.5 \mathrm{~cm}$ in June. Precipitation during the study period was slightly above the average in May and July and 33 and $80 \%$ below average in June and August, respectively. Vegetation is dominated by a mixture of mid and tall grasses. Big bluestem (Andropogon gerardii), a warmseason grass, and Kentucky bluegrass (Poa pratensis)are the dominant species of depressions. Green needlegrass (Stipa viridula) and Kentucky bluegrass, both cool-season species, dominate the upland sites. In most years the depressions provide additional run-in water for forage growth, which results in continuous, season-long, heavy grazing pressure on these sites. Cool-season species on upland sites usually mature early in the grazing season as soil water is depleted. Grazing pressure is concentrated on vegetation in depressions because of continuous forage growth throughout the summer.

The 162-ha study pasture was grazed with yearling steers at approximately 1.7 AUM's/ha from May 28 to August 28. Steers weighed an average of $330 \mathrm{~kg}$ at the beginning and $358 \mathrm{~kg}$ at the end of the study period.

In mid-June 13 potholes in the study pasture contained ponded water. Treatments were randomly assigned to these potholes. On July 20 , a commercially available deer and elk repellent with an active ingredient of putrescent whole egg solids was applied in a liquid spray at about $1401 /$ ha to a narrow band of vegetation encircling 6 potholes. The mid-season treatment date was selected since it was believed that substantial grazing pressure on subirrigated range sites would not normally occur until late July. The treated vegetation was dominated by big bluestem, characteristic dominant of the subirrigated range site. Seven other potholes were selected for comparison and were not treated with the repellent.

Distribution of yearling steers were measured by bi-weekly cow chip counts on 2 belt transects $(3 \mathrm{~m} \times 30 \mathrm{~m})$ located at each pothole. To avoid double counting, newly deposited cow chips were identified by spray paint at each enumeration date. One transect was located along the edge of the pothole in the big bluestem dominated vegetation (subirrigated range site) and the other was located $25 \mathrm{~m}$ upslope in green needlegrass-Kentucky bluegrass dominated vegetation (silty range site). Cow chip counts have been suggested as an indicator of relative time spent on various areas of a range (Julander 1955, Mueggler 1965, Cook 1966). 


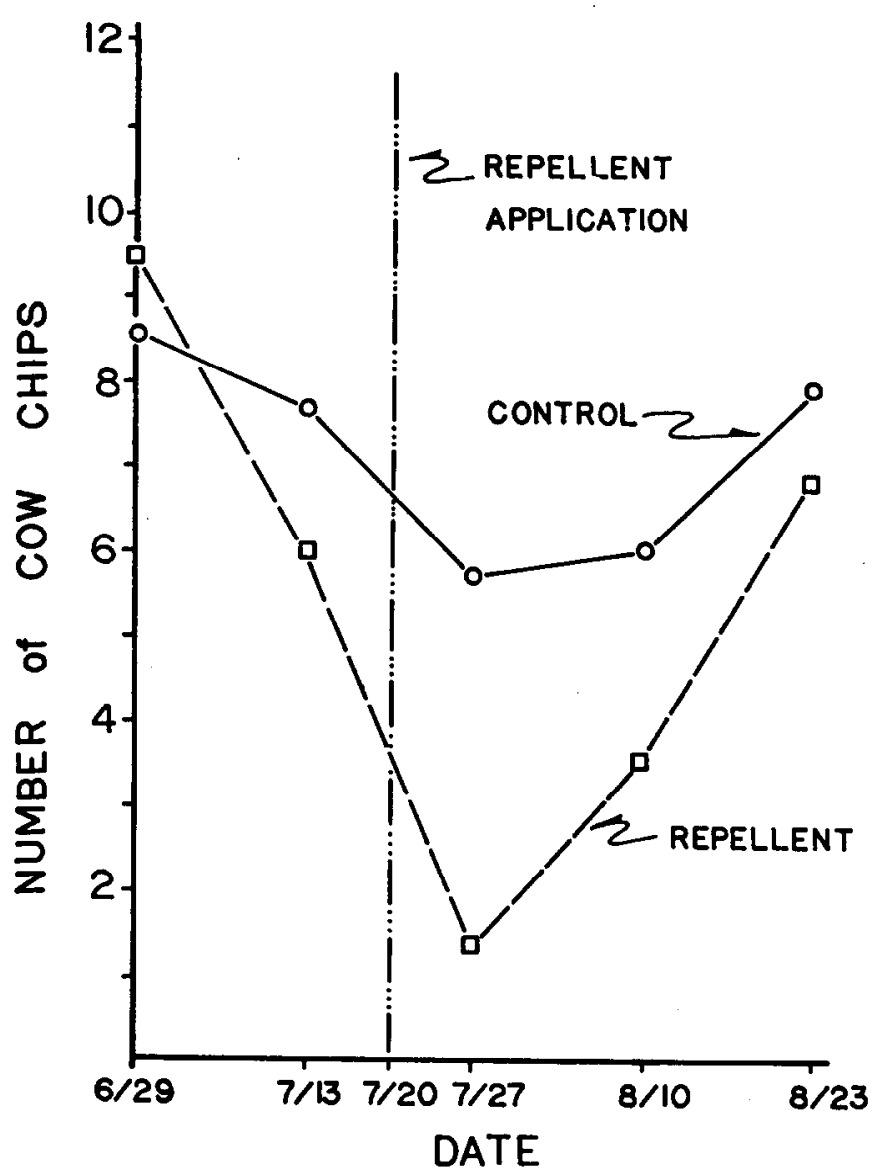

Fig. 1. Least squares means of cow chip numbers on subirrigated range sites.

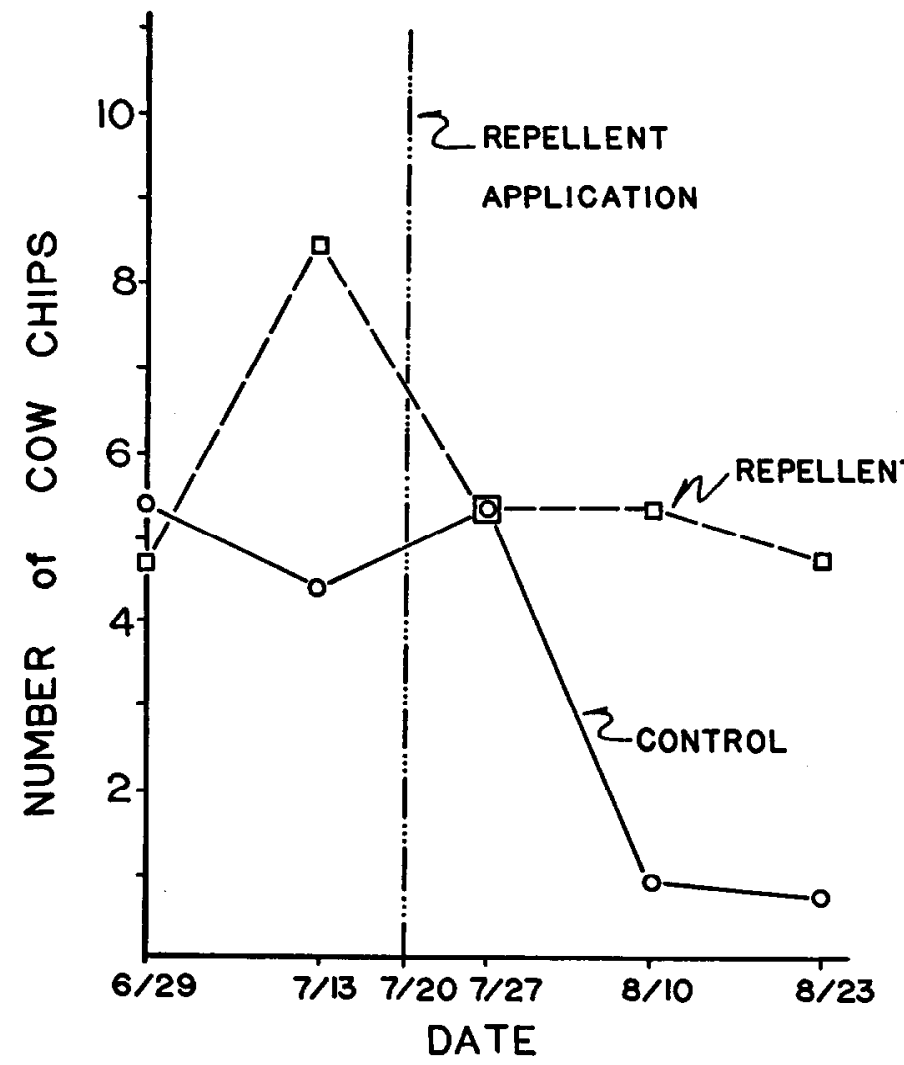

Fig. 2. Least squares means of cow chip numbers on silty range sites.
Analysis of variance was performed on cow chip data by the General Linear Model procedure in the Statistical Analysis System (Barr et al. 1979). Data from 5 cow chip counts were analyzed as split plots over time. Tukey's $w$-procedure was used to compute range values for mean separations (Steele and Torrie 1960). The 2 hypotheses tested in this analysis were: (1) The repellent was effective in controlling the grazing distribution of yearling steers, and (2) the repellent was equally effective in repelling yearling steers from repellent sprayed subirrigated sites and adjacent silty range sites.

\section{Results and Discussion}

The least squares means of the number of cow chips counted by dates were: 7.04 on June $29 ; 6.66$ on July $13 ; 4.47$ on July $27 ; 3.92$ on August 10; and 5.02 on August 23. Less than $1.0 \%$ of the variation in cow chip numbers was accounted for by treatment. Steers deposited significantly more $(P<.05)$ fecal groups on the subirrigated than the silty sites ( 6.30 and 4.54 , respectively) over the entire study period.

The effect of the repellent on occupation of yearling steers as estimated by cow chips is shown in Figures 1 and 2 for subirrigated and silty range sites, respectively. The repellent did not significantly affect the number of cow chips counted on any date on either site. Although not statistically significant there was an indication that the repellent was responsible for a short-term decline in cow chips deposited on the subirrigated site. Later in the growing season $(8 / 10$ and $8 / 23)$, the number of cow chips deposited on the repellent silty range sites adjacent to repellent treated subirrigated sites stayed at a high level whereas there was a decrease in the cow chips deposited on the control silty sites. Also, the mean number of cow chips counted for all sampling dates was significantly higher on silty range sites adjacent to repellent treated subirrigated range sites than on control silty range sites. This indicates a marginal displacment of the steers from the repellent-treated subirrigated site.

Cattle possibly develop preferred areas early in the grazing season. At the time of the repellent application (July 20), precipitation was below the monthly average and forage on silty sites had ceased active growth. Steers were probably attracted by lush, actively growing vegetation on the subirrigated sites by early June. To protect conifor seedlings from deer and elk browsing the repellent manufacturer's label instructions suggest application at the onset of browsing. In this study the repellent was applied after steer grazing preferences were probably fixed. An earlier application of the repellent may have increased its effectiveness.

Further studies with repellents to manipulate distribution of livestock on rangelands are warranted. In cases where management alternatives prohibit the application of conventional distribution techniques, repellents may offer a viable method of obtaining selective nonuse of rangelands.

\section{Literature Cited}

Barr, A.J., J.H. Goodnight, J.P. Sall, and J.T. Helwig. 1979. A user guide to SAS 79. SAS Institute, Gary, N. C.

Cook, C.W. 1966. Factors affecting utilization of mountain slopes by cattle. J. Range Manage. 19:200-204.

Julander, O. 1955. Determining grazing use by cow chip counts. J. Range Manage. 8:182.

Martin, S.C., and D.E. Ward. 1973. Salt and meal-salt help to distribute cattle use on semidesert range. J. Range Manage. 26:94-97.

Mueggler, W.E. 1965. Cattle distribution on steep slopes. J. Range Manage. 18:255-257.

Rosth, L.R., and W.C. Krueger. 1982. Cattle grazing and behavior on a forested range. J. Range Manage. 35:332-338.

Steele, R.G.D. and J.H. Torrie. 1960. Principles and procedures of statistics. McGraw-Hill Book co. Inc. N.Y.

Workman, J.P., and J.F. Hooper. 1968. Preliminary economic evaluation of cattle distribution practices on mountain rangelands. J. Range Manage. 21:301-304. 